\title{
Renaming of Agrobacterium larrymoorei Bouzar and Jones 2001 as Rhizobium larrymoorei (Bouzar and Jones 2001) comb. nov.
}

Correspondence

J. M. Young

youngj@LandcareResearch.co.nz

\author{
J. M. Young \\ Landcare Research, Private Bag 92170, Auckland, New Zealand
}

In conformity with the nomenclature of the genus Rhizobium published by Young et al. (Int $\mathrm{J}$ Syst Evol Microbio/ 51, 89-103, 2001), it is proposed that Agrobacterium larrymoorei be named as Rhizobium larrymoorei comb. nov.
A gall-forming pathogen from Ficus benjamina (Bouzar et al., 1995) was subsequently characterized and named Agrobacterium larrymoorei (Bouzar \& Jones, 2001). Comparative analysis of $16 \mathrm{~S}$ rDNA sequences gives an inferred phylogeny of this species as being closely related to other agrobacteria on a larger clade comprising known Rhizobium species (Bouzar \& Jones, 2001) and other Agrobacterium species (Young et al., 2001). Following their analysis of available data, Young et al. (2001) proposed that species in Agrobacterium were members of an artificial genus established only on pathogenicity characters that were carried on transferable plasmid-borne genes. Because there are no other data to support the differentiation of Agrobacterium as a distinct genus, Young et al. (2001) proposed that all Agrobacterium species were more properly considered to be members of Rhizobium. This is also true for Agrobacterium larrymoorei. Following Rule 34a of the International Code of Nomenclature of Bacteria (Prokaryotes) (Lapage et al., 1992), it is proposed that the epithet larrymoorei be applied to this species as a new combination in Rhizobium. Those who wish to use a nomenclature that reflects natural and polyphasic relationships as presently understood may prefer this nomenclature to the specialpurpose use of Agrobacterium. The alternative name Rhizobium larrymoorei is proposed for this species.

\section{Description of Rhizobium larrymoorei comb. nov.}

The description is that given by Bouzar \& Jones (2001). The type strain is ATCC $51759^{\mathrm{T}}=\mathrm{CFBP} 5473^{\mathrm{T}}=\mathrm{ICMP}$ $14256^{\mathrm{T}}=$ NCPPB $4096^{\mathrm{T}}$.

\section{References}

Bouzar, H. \& Jones, J. B. (2001). Agrobacterium larrymoorei sp. nov., a pathogen isolated from aerial tumours of Ficus benjamina. Int J Syst Evol Microbiol 51, 1023-1026.

Bouzar, H., Chilton, W. S., Nesme, X., Dessaux, Y., Vaudequin, V., Petit, A., Jones, J. B. \& Hodge, N. C. (1995). A new Agrobacterium strain isolated from aerial tumors on Ficus benjamina L. Appl Environ Microbiol 61, 65-73.

Lapage, S. P., Sneath, P. H. A., Lessel, E. F., Skerman, V. B. D., Seeliger, H. P. R. \& Clark, W. A. (editors) (1992). International Code of Nomenclature of Bacteria (1990 Revision). Bacteriological Code. Washington, DC: American Society for Microbiology.

Young, J. M., Kuykendall, L. D., Martínez-Romero, E., Kerr, A. \& Sawada, H. (2001). A revision of Rhizobium Frank 1889, with an emended description of the genus, and the inclusion of all species of Agrobacterium Conn 1942 and Allorhizobium undicola de Lajudie et al. 1998 as new combinations: Rhizobium radiobacter, R. rhizogenes, R. rubi, R. undicola and R. vitis. Int J Syst Evol Microbiol 51, 89-103. 